\title{
Determination of Immunoreactive Somatostatin in Rat Plasma and Responses to Arginine, Glucose and Glucagon Infusion
}

\author{
M. Utsumi, H. Makimura, K. Ishihara, S. Morita, and S. Baba \\ Second Department of Internal Medicine, Kobe University School of Medicine, Kobe, Japan
}

Summary. A method for the determination of immunoreactive somatostatin in rat plasma is described. Blood specimens were collected into aprotinin and EDTA. Plasma was separated, immediately diluted with acidified acetone and ultrasonicated. The resultant supernatant was lyophilised. The dilution curve of the material thus extracted was parallel to that of synthetic somatostatin. The material was eluted mainly in a similar position to that of synthetic somatostatin on Sephadex G25(f) column chromatography. The somatostatin immunoreactivity was degraded significantly from the pre-incubated value of $846 \pm 86 \mathrm{pg} / \mathrm{ml}(\mathrm{n}=4$, mean $\pm \mathrm{SEM}$ ) to $102 \pm 16 \mathrm{pg} / \mathrm{ml}$ in the same manner as that of synthetic somatostatin when incubated with one $\mathrm{ml}$ of fresh rat plasma at $37^{\circ} \mathrm{C}$ for $30 \mathrm{~min}$. The mean recovery in quadruplicate of immunoreactive somatostatin at concentrations of 100,200 and $400 \mathrm{pg} / \mathrm{ml}$ was $83 \pm 7,95 \pm 4$ and $76 \pm 4 \%$, respectively. Using this method, plasma immunoreactive somatostatin responses to arginine, glucose and glucagon infusion were measured in pentobarbital anaesthetized rats. The mean basal plasma immunoreactive somatostatin concentration in the jugular vein was $35 \pm 3 \mathrm{pg} / \mathrm{ml}(\mathrm{n}=7)$, while that in the hepatic portal vein was $120 \pm 17 \mathrm{pg} / \mathrm{ml}(\mathrm{n}=7)$. Infusion of arginine, glucose and glucagon all resulted in 2-3 fold increases in portal plasma immunoreactive somatostatin concentration.

Key words: Somatostatin, radioimmunoassay, rat plasma, acidified acetone extraction, assay validity, jugular vein, portal vein, arginine, glucose, glucagon, infusion.
Somatostatin, a tetradecapeptide originally isolated and characterized from ovine hypothalami, has been demonstrated to exist not only in the central nervous system, but also in the gut and the pancreas [1]. Recent studies in isolated pancreatic islets incubated with somatostatin antiserum have raised the possibility that pancreatic somatostatin may exert physiological control in the secretion of insulin and glucagon $[2,3]$. Furthermore, several investigations have revealed that the secretion of pancreatic or gastric somatostatin is stimulated by glucose and other insulin secretagogues in vitro $[4,5,6,7]$. However, reports concerning circulating blood somatostatin levels differ with regard to the properties of somatostatin in plasma and the response to various stimuli $[8,9,10,11,12,13,14,15,16]$.

In the present report, we describe a method of radioimmunoassay for somatostatin in rat plasma and the changes of portal plasma somatostatin level to arginine, glucose and glucagon infusion.

\section{Materials and Methods}

\section{Radioimmunoassay for Somatostatin}

Antiserum to cyclic somatostatin (Protein Research Foundation, No 4023, Osaka, Japan) was produced in rabbits according to the method of Arimura et al. [17] and used at a final dilution of $1: 8000$. The antiserum used in this study had no cross - reactivity with thyrotrophin releasing hormone, luteinizing hormone releasing hormone, substance $P$, neurotensin, oxytocin, secretin, gastric inhibitory polypeptide, vasoactive intestinal polypeptide, motilin, insulin, glucagon and pancreatic polypeptide. Tyr' ${ }^{1}$ somatostatin (Protein Research Foundation, No 760220) was labelled with ${ }^{125} \mathrm{I}$ by the method of Hunter and Greenwood [18] and purified on a Sephadex G-25(f) column. Synthetic cyclic somatostatin was used as a reference standard. The diluent for assay was $1 \mathrm{~g} / 100 \mathrm{ml}$ bovine serum albumin (BSA), $0.15 \mathrm{~mol} / 1$ $\mathrm{NaCl}, 0.002 \mathrm{~mol} / \mathrm{l}$ EDTA, $0.025 \mathrm{~mol} / 1$ benzamidine hydro- 


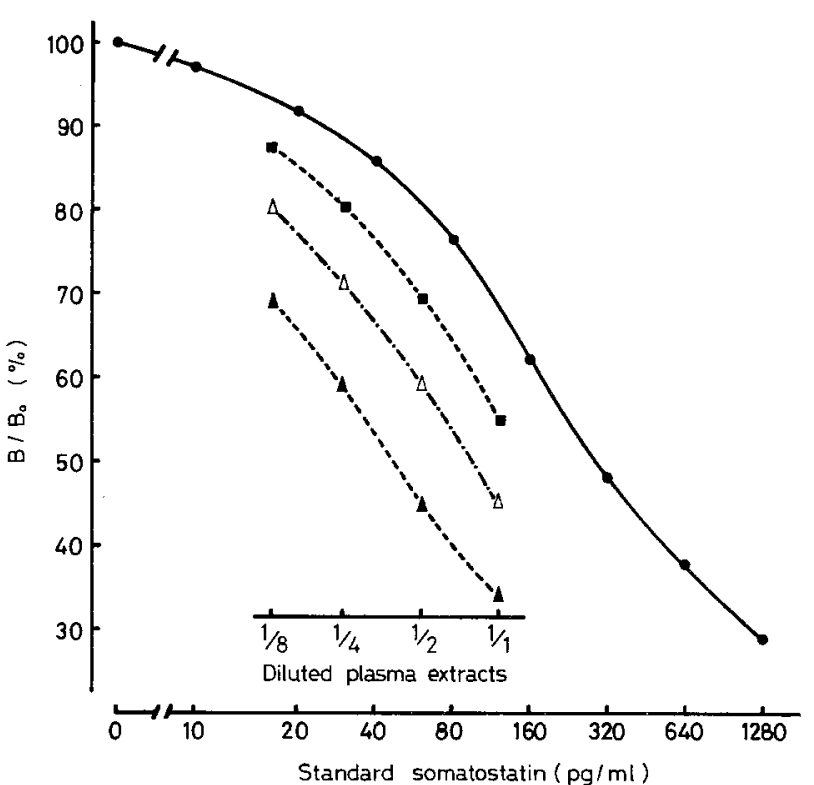

Fig. 1. Standard curve for somatostatin radioimmunoassay and dilution curves of portal and jugular plasma extracts. Mean percentage binding of labelled somatostatin in the absence of unlabelled somatostatin was $33 \pm 2 \%$. Ten $\mathrm{ml}$ of plasma were pooled and extracted by acidified acetone immediately $(\boldsymbol{\Delta}---\boldsymbol{\Delta}$ portal plasma; - - $\mathbf{\square}$ jugular plasma) or after the incubation at $37^{\circ} \mathrm{C}$ for $10 \mathrm{~min}(\triangle-\cdot-\cdot-\Delta$ portal plasma $)$

Table 1. Inactivation of the somatostatin immunoreactivity in plasma extracts and synthetic somatostatin by fresh rat plasma

\begin{tabular}{llc}
\hline Material & \multicolumn{2}{c}{ Somatostatin immunoreactivity $(\mathrm{pg} / \mathrm{ml})$} \\
\cline { 2 - 3 } & Pre-incubated & Incubated \\
\hline $\begin{array}{l}\text { Plasma extracts } \\
(\mathrm{n}=4)\end{array}$ & $846 \pm 86$ & $102 \pm 16^{\mathrm{a}}$ \\
$\begin{array}{l}\text { Synthetic somatostatin } \\
(\mathrm{n}=4)\end{array}$ & $859 \pm 57$ & $109 \pm 13^{\mathrm{a}}$ \\
\hline
\end{tabular}

Five $\mathrm{ml}$ of portal plasma were extracted and lyophilised. The plasma extracts and synthetic somatostatin $(1 \mathrm{ng})$ were incubated with one $\mathrm{ml}$ of fresh rat plasma at $37^{\circ} \mathrm{C}$ for $30 \mathrm{~min}$. Results are

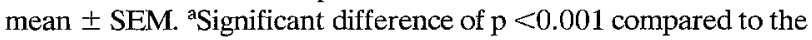
pre-incubated value

chloride, $0.01 \mathrm{~mol} / 1$ phosphate buffer, $\mathrm{pH} 7.6$. Each point on the standard curve was in triplicate. Separation of antibody-bound from free labelled-hormone was accomplished by a double-antibody method [19].

\section{Animal Experiments}

Male Wistar rats weighing about $250 \mathrm{~g}$ were used in the fully fed state. Animals were anaesthetized with sodium pentobarbital (50 $\mathrm{mg} / \mathrm{kg}$ body weight, IM) between 9:00-10:00 a. $\mathrm{m}$. and a laparotomy performed. One ml of portal blood was collected into a test tube containing aprotinin (Trasylol, 1000 Kallikrein inactivator units $/ \mathrm{ml})$ and disodium EDTA $(1.2 \mathrm{mg} / \mathrm{ml})$ through a polyethylene tube inserted into the hepatic portal vein from the ileocaecal side of the superior mesenteric vein. Plasma was immediately separated and diluted with 4 volumes of acidified acetone (purified acetone: $1 \mathrm{~mol} / 1 \mathrm{HCl}, 100: 2$ by volume, $\mathrm{pH} 3.0$ ) and ultrasonicated for $30 \mathrm{sec}$ at 50 watts (Branson Sonic Power Co., Danburg, USA). The resultant supernatant was then lyophilised under vacuum. The material was stored at $-20^{\circ} \mathrm{C}$ until somatostatin assay.

The properties of immunoreactive somatostatin in plasma were examined by the following experiments. The inactivation of immunoreactive somatostatin extracted from portal plasma (endogenous) was compared to that of synthetic somatostatin (exogenous). The lyophilised material ( $5 \mathrm{ml}$ plasma) and synthetic cyclic somatostatin (Protein Research Foundation, No 4023, Osaka, Japan, $1 \mathrm{ng}$ ) were incubated with one $\mathrm{ml}$ of fresh rat plasma at $37^{\circ} \mathrm{C}$ for $30 \mathrm{~min}$ and extracted thereafter with acidified acetone. The residual immunoreactive somatostatin was measured. To examine the chromatographic pattern of plasma immunoreactive somatostatin, the lyophilised material obtained from ten $\mathrm{ml}$ of portal plasma was eluted on a Sephadex G-25(f) column $(0.8 \times 30 \mathrm{~cm})$ with $0.1 \mathrm{~mol} / \mathrm{l}$ acetic acid containing $0.25 \mathrm{~g} /$ $100 \mathrm{ml} \mathrm{BSA}, \mathrm{pH}$ 3.0. Blood was also withdrawn simultaneously from the jugular and portal veins before and 2 min after a single IV administration of arginine hydrochloride $(500 \mathrm{mg} / \mathrm{kg}$ body weight). Arginine $(100 \mathrm{mg} / \mathrm{kg}$ body weight $/ \mathrm{min})$, glucose $(100 \mathrm{mg} /$ $\mathrm{kg}$ body weight $/ \mathrm{min})$ and glucagon $(1 \mu \mathrm{g} / \mathrm{kg}$ body weight $/ \mathrm{min})$ were also infused via the jugular vein at a constant rate of $0.1 \mathrm{ml} /$ $\mathrm{min}$ for $20 \mathrm{~min}$ and one $\mathrm{ml}$ of portal blood was collected at $0,2,5$, $10,15,20,25$ and $30 \mathrm{~min}$, respectively. In these experiments, all rats received their packed cells dissolved with $0.154 \mathrm{~mol} / \mathrm{l}$ saline immediately following blood sampling.

\section{Other Determinations}

Plasma glucose was measured by the glucose oxidase method. Plasma insulin (IRI) and glucagon (IRG) were determined by radioimmunoassay using guinea pig anti-porcine insulin serum and rat insulin as a standard [20] and using $30 \mathrm{~K}$ anti-glucagon serum and porcine glucagon as a standard [21], respectively.

Statistical analysis of data was performed by Student's $t$ test. Results are expressed as mean \pm SEM.

\section{Results}

\section{Radioimmunoassay for Plasma Somatostatin}

Figure 1 represents a standard curve of somatostatin radioimmunoassay and dilution curves of rat plasma extracts. In this assay, $20 \mathrm{pg} / \mathrm{ml}$ could be detected when it was used 2 SD above the zero value in 5 replicate assays. Mean percentage binding of labelled somatostatin in the absence of unlabelled somatostatin was $33 \pm 2 \%$ for 12 different assays. Serial dilutions of plasma extracts were proportional and their dilution slopes parallel with that of the standard.

The immunoreactive somatostatin (endogenous; IRS) in the extracted material was degraded significantly in the same manner as synthetic somatostatin (exogenous) (Table 1). The main peak of the elution pattern of the material was similar to that of authentic somatostatin when it was applied to a Sephadex G-25(f) column (Figure 2). The mean recovery of synthetic somatostatin added to plasma was $83 \pm 7$, 


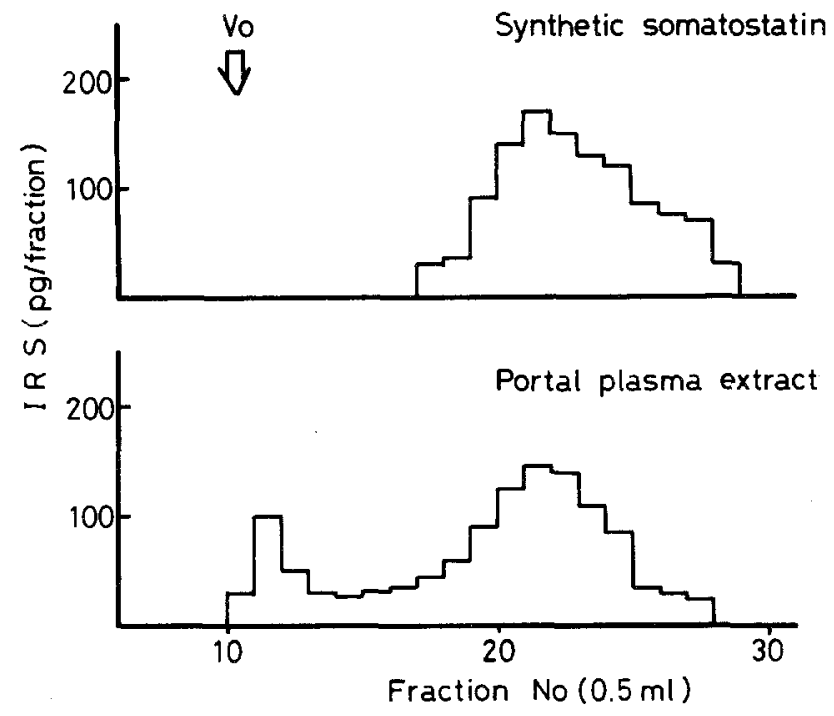

Fig. 2. Elution pattern of immunoreactive somatostatin (IRS) in the plasma extracts on a Sephadex G-25(f) column. Recovery of synthetic somatostatin ( $2 \mathrm{ng}$ ) applied to the column was $60 \%$. IRS in each fraction was measured after lyophilisation. $\mathrm{V}_{\mathrm{o}}$ : void volume

$95 \pm 4$ and $76 \pm 4 \%(n=4)$ at concentrations of 100,200 and $400 \mathrm{pg} / \mathrm{ml}$, respectively. The intraassay coefficients of variation ranged from 6.6 to $8.7 \%$ and the interassay coefficients of variation from 6.9 to $11.9 \%$, respectively.

\section{Comparison of Jugular and Portal Plasma IRS Levels}

The mean basal plasma IRS level in the portal vein was approximately threefold higher than that in the jugular vein (Table 2). Two min after a single IV administration of arginine both levels increased significantly and the ratio of the portal plasma to the jugular IRS was higher than before the arginine injection (Table 2). As expected, plasma IRI and IRG concentration were significantly higher in the portal vein than in the jugular vein.

\section{Effects of Arginine, Glucose and Glucagon Infusion on Portal Plasma IRS Levels}

The infusion of arginine resulted in a prompt and significant increase in portal plasma IRS concentrations from a mean basal value of $105 \pm 17 \mathrm{pg} / \mathrm{ml}$ (n $=7)$ to a peak value of $353 \pm 55 \mathrm{pg} / \mathrm{ml}(\mathrm{p}<0.005$ against the saline control) at $15 \mathrm{~min}$. On stopping the arginine infusion, values declined gradually toward the control (Figure 3). Arginine infusion was associated with a similar rise in IRI and IRG levels. During the infusion of glucose, portal plasma IRS concentration rose significantly from a basal value of $126 \pm$ $14 \mathrm{pg} / \mathrm{ml}$ to $343 \pm 50 \mathrm{pg} / \mathrm{ml}(\mathrm{p}<0.01)$ at $5 \mathrm{~min}$ and

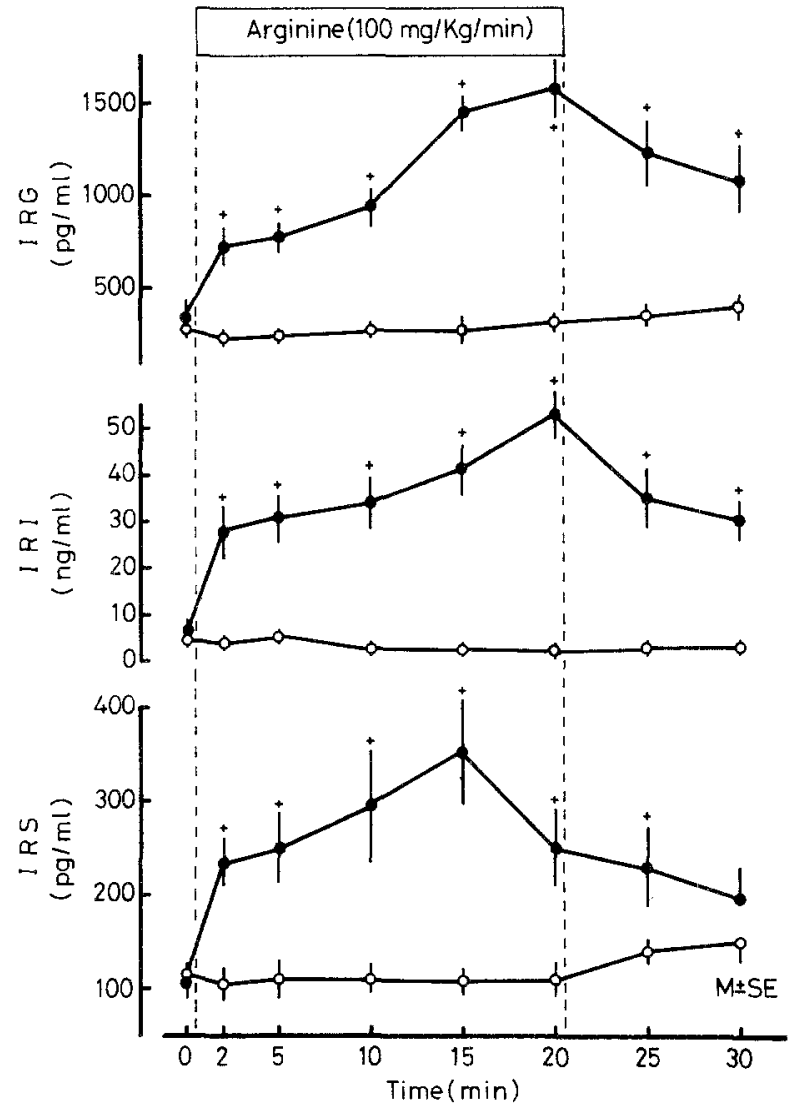

Fig. 3. Effect of arginine infusion ( $100 \mathrm{mg} / \mathrm{kg}$ body weight $/ \mathrm{min})$ for $20 \mathrm{~min}$ on portal plasma immunoreactive glucagon (IRG), insulin (IRI) and somatostatin (IRS) levels in rats arginine $(\mathrm{n}=7) ; 0-0$, saline control $(\mathrm{n}=7)$ Significance of difference: $(+) p<0.05$ or less compared to the saline control at the corresponding time periods

Table 2. Comparison of plasma immunoreactive somatostatin (IRS), insulin (IRI) and glucagon (IRG) levels in the jugular and the portal vein of the rat

\begin{tabular}{llrll} 
& Vein & \multicolumn{1}{l}{$\begin{array}{l}\text { IRS } \\
(\mathrm{pg} / \mathrm{ml})\end{array}$} & $\begin{array}{l}\text { IRI } \\
(\mathrm{ng} / \mathrm{ml})\end{array}$ & $\begin{array}{l}\text { IRG } \\
(\mathrm{pg} / \mathrm{ml})\end{array}$ \\
\hline Basal $(\mathrm{n}=7)$ & jugular & $35 \pm 3$ & $2.8 \pm 0.1$ & $103 \pm 10$ \\
& portal & $120 \pm 17$ & $6.2 \pm 0.6$ & $165 \pm 16$ \\
$\begin{array}{l}\text { Post-arginine } \\
(\mathrm{n}=7)\end{array}$ & jugular & $68 \pm 6$ & $8.4 \pm 0.6$ & $286 \pm 22$ \\
& portal & $267 \pm 32$ & $29.7 \pm 3.9$ & $574 \pm 62$
\end{tabular}

Blood from the jugular and the portal vein was withdrawn simultaneously before and 2 min after a single IV administration of arginine $(500 \mathrm{mg} / \mathrm{kg}$ body weight). All values represent mean \pm SEM

$334 \pm 40 \mathrm{pg} / \mathrm{ml}(\mathrm{p}<0.005)$ at $20 \mathrm{~min}$. However, the cessation of glucose infusion failed to lower the levels by $30 \mathrm{~min}$, when plasma glucose levels still remained higher than control (Figure 4). The infusion of glucagon was also followed by a gradual but significant rise in portal plasma IRS level from a basal value of $99 \pm$ 


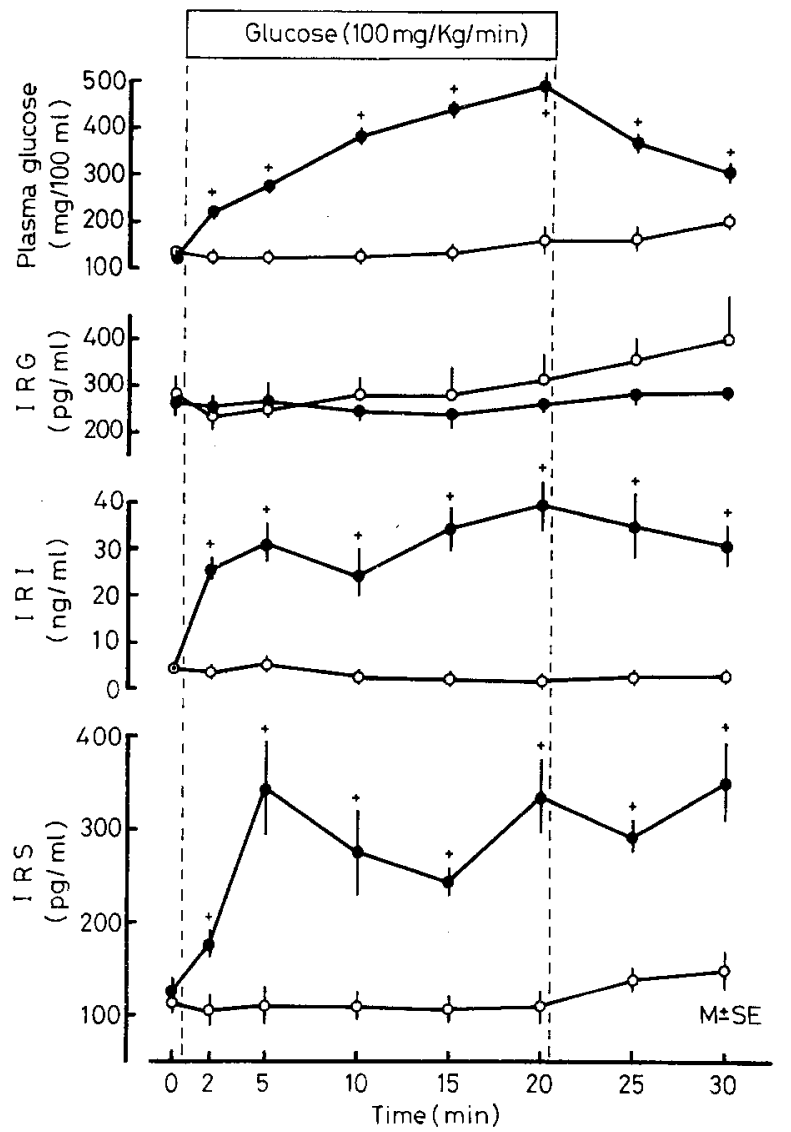

Fig. 4. Effect of glucose infusion ( $100 \mathrm{mg} / \mathrm{kg}$ body weight $/ \mathrm{min}$ ) for $20 \mathrm{~min}$ on portal plasma glucose, immunoreactive glucagon (IRG), insulin (IRI) and somatostatin (IRS) levels in rats. - glucose $(\mathrm{n}=7) ; 0-O$, saline control $(\mathrm{n}=7)$ Significance of difference: $(+) \mathrm{p}<0.05$ or less compared to the saline control at the corresponding time periods

$8 \mathrm{pg} / \mathrm{ml}$ to $283 \pm 35 \mathrm{pg} / \mathrm{ml}(\mathrm{p}<0.005)$ at $20 \mathrm{~min}$. The level reached a peak of $300 \pm 39 \mathrm{pg} / \mathrm{ml}(\mathrm{p}$ $<0.005$ ) at $25 \mathrm{~min}$ (Figure 5). The plasma glucose continued to rise on stopping the glucagon infusion.

\section{Discussion}

Arimura et al. [11, 17] have reported the presence of non-somatostatin substances in plasma interfering non-specifically with the assay system. The substances, presumed to be unknown macromolecules in plasma, could be removed with organic solvents, while synthetic somatostatin added to plasma could be recovered satisfactorily. On the other hand, some authors $[13,14]$ have demonstrated that immunoreactive somatostatin circulates in blood bound to macromolecules and could be measured in unextracted plasma. This discrepancy needs to be clarified.

In the present study, the extraction of somatostatin from rat plasma was performed by a modification

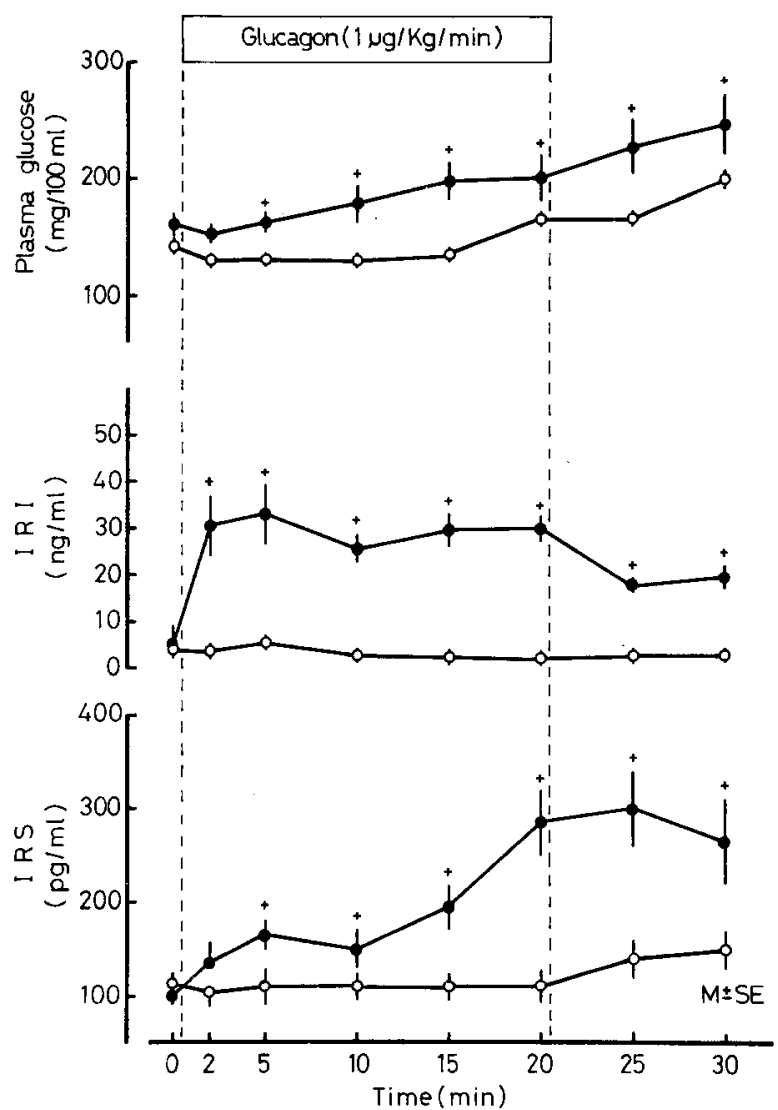

Fig. 5. Effect of glucagon infusion ( $1 \mu \mathrm{g} / \mathrm{kg}$ body weight/min) for $20 \mathrm{~min}$ on portal plasma glucose, immunoreactive insulin (IRI) and somatostatin (IRS) levels in rats. -—, glucagon $(\mathrm{n}=6)$; $\bigcirc-O$, saline control $(n=7)$ Significance of difference: $(+)$ $p<0.05$ or less compared to the control at the corresponding time periods

of the method of Arimura et al. [11]. The parallellism of the dilution curve of the extracted material with that of synthetic somatostatin and the chromatographic similarity on a Sephadex G-25(f) column suggest that the immunoreactive somatostatin in the plasma extract is immunologically indistinguishable from the synthetic tetradecapeptide. On gel filtration, a small peak of somatostatin immunoreactivity was observed at the void volume of the column. In addition, the somatostatin immunoreactivity was almost entirely degraded by incubation with fresh plasma. It is well known that exogenous and endogenous somatostatin are rapidly inactivated in brain tissues and blood, in which the process of the degradation is assumed to be enzymatic [22, 23, 24]. This indicates that the substance measured as somatostatin in plasma may be identical to synthetic somatostatin.

The data in Table 2 reveal regional differences in plasma somatostatin concentrations consistent with other recent investigations $[8,9,15]$. In the rat, there is a fourfold difference between the somatostatin 
levels in the portal vein reported by Berelowitz et al. [9] and those in this study. This may be attributed to the different assay system and extraction procedure. It may be that considerable protein-bound somatostatin is precipitated by the organic solvent. The immunoreactivity associated with the plasma precipitate as well as with the supernatant needs to be investigated. The transhepatic gradient of plasma immunoreactive somatostatin indicates that the quantity of somatostatin secreted into the portal vein from the gut and the pancreas is greater than that from the central nervous system.

There are many reports indicating that insulin secretogogues such as glucose, arginine and glucagon stimulate the release of somatostatin in vitro $[4,5,6$, 7]. The present data confirm that the infusion of these agents causes the secretion of somatostatin in vivo. However, our results are not consistent with studies by Gustavsson and Lundqvist [15], who reported that intravenous glucose administration caused a decrease in peripheral plasma somatostatin level in anaesthetized pigs and by Schusdziarra et al. [16] who found that the infusion of glucose was associated with a decrease in peripheral plasma somatostatin level in normal conscious dogs. These discrepancies remain to be clarified.

\section{References}

1. Vale, W., Rivier, C., Brown, M.: Regulatory peptides of the hypothalamus. Annu. Rev. Physiol. 39, 473-527 (1977)

2. Taniguchi, H., Utsumi, M., Hasegawa, M., Kobayashi, T., Watanabe, Y., Murakami, K., Seki, M., Tsutou, A., Makimura, H., Sakoda, M., Baba, S.: Physiologic role of somatostatin - Insulin release from rat islets treated by somatostatin antiserum. Diabetes 26, 700-702 (1977)

3. Barden, N., Lavoie, M., Dupont, A., Cote, J., Cote, J.-P.: Stimulation of glucagon release by addition of anti-somatostatin serum to islets of Langerhans in vitro. Endocrinology 101, 635-638 (1977)

4. Schauder, P., McIntosh, C., Arends, J., Arnold, R., Frerichs, H., Creutzfeldt, W.: Somatostatin and insulin release from isolated rat pancreatic islets stimulated by glucose. FEBS Lett. 68, 225-227 (1976)

5. Ipp, E., Dobbs, R. E., Arimura, A., Vale, W., Harris, V., Unger, R. H.: Release of immunoreactive somatostatin from the pancreas in response to glucose, amino acids, pancreozymin-cholecyctokinin, and tolubutamide. J. Clin. Invest. 60, 760-765 (1977)

6. Effendic, S., Nylen, A., Roovete, A., Uvnäs-Wallenstein, K. Effects of glucose and arginine on the release of immunoreactive somatostatin from the isolated perfused rat pancreas. FEBS Lett. 92, 33-35 (1978)

7. Chiba, T., Seino, Y., Goto, Y., Kadowaki, S., Taminato, T., Abe, H., Kato, Y., Matsukura, S., Nozawa, M., Imura, H.: Somatostatin release from isolated perfused rat stomach. Biochem. Biophys. Res. Commun. 82, 731-737 (1978)

8. Schusdziarra, V., Dobbs, R. E., Harris, V., Unger, R. H.: Immunoreactive somatostatin levels in plasma of normal and alloxan diabetic dogs. FEBS Lett. 81, 69-72 (1977)
9. Berelowitz, M., Kronheim, S., Pimstone, B., Shapiro, B.: Somatostatin-like immunoreactivity in rat blood. J. Clin. Invest. 61, 1410-1414 (1978)

10. Harris, V., Conlon, J.M., Srikant, C. B., McCorkle, K. Schusdziarra, V., Ipp, E., Unger, R. H.: Measurement of somatostatin-like immunoreactivity in plasma. Clin. Chim. Acta 87, 275-283 (1978)

11. Arimura, A., Lundqvist, G., Rothman, J., Chang, R., Fernando-Durango, R., Elde, R., Coy, H., Meyers, C., Schally, A. V.: Radioimmunoassay of somatostatin. Metabolism 27 (Suppl. 1), 1139-1144 (1978)

12. Schusdziarra, V., Harris, V., Conlon, J.M., Arimura, A., Unger, R. H.: Pancreatic and gastric somatostatin release in response to intragastric and intraduodenal nutrients and $\mathrm{HCl}$ in the dog. J. Clin. Invest. 62, 509-518 (1978)

13. Conlon, J. M., Srikant, C. B., Ipp, E., Schusdziarra, V., Vale, W., Unger, R. H.: Properties of endogenous somatostatin-like immunoreactivity and synthetic somatostatin in dog plasma. $\mathrm{J}$. Clin. Invest. 62, 1187-1193 (1978)

14. Vale, W., Rivier, J., Ling, N., Brown, M.: Biologic and immunologic activities and applications of somatostatin, Metabolism 27 (Suppl. 1), 1391-1401 (1978)

15. Gustavsson, S., Lundqvist, G.: Inhibition of pancreatic somatostatin release in response to glucose. Biochem. Biophys. Res. Commun. 82, 1229-1235 (1978)

16. Schusdziarra, V., Rouiller, D., Harris, V. J., Conlon, M., Unger, R. H.: The responses of plasma somatostatin-like immunoreactivity to nutrients in normal and alloxan diabetic dogs. Endocrinology 103, 2264-2273 (1978)

17. Arimura, A., Sato, H., Coy, D. H., Schally, A. V.: Radioimmunoassay for GH-release inhibiting hormone. Proc. Soc. Exp. Biol. Med. 148, 784-789 (1975)

18. Hunter, V. M., Greenwood, F. C.: Preparation of Iodine-131 labeled human growth hormone of high specific activity. Nature 194, 495-496 (1962)

19. Utsumi, M., Makimura, H., Sakoda, M., Baba, S.: Radioimmunoassay for somatostatin. Folia Endocrinol. Jpn. 53, 221-234 (1977) (in Japanese)

20. Desbuquois, B., Aurbach, G. D.: Use of polyethylene glycol to separate free and antibody-bound peptide hormones in radioimmunoassays. J. Clin. Endocrinol. Metab. 33, 732-738 (1971)

21. Aguilar-Parada, E., Eisentraut, E. M., Unger, R. H.: Pancreatic glucagon secretion in normal and diabetic subjects. Am. J. Med. Sci. 257, 415-419 (1969)

22. Marks, N., Stern, F.: Inactivation of somatostatin (GH-RIH) and its analogs by crude and partially purified rat brain extracts. FEBS Lett. 55, 220-224 (1975)

23. Griffiths, E. C., Jeffcoate, S. L., Holland, D. T.: Inactivation of somatostatin by peptidases in different areas of the rat brain. Acta Endocrinol. (Kbh.) 85, 1-10 (1977)

24. Utsumi, M., Makimura, H., Ishihara, K. K., Baba, S.: Inactivation of somatostatin by serum and brain tissues. Clin. Endocrinol. (Tokyo) 6, 558-560 (1978) (in Japanese)

Received: February 2, 1979,

and in revised form: May 23, 1979

Masafumi Utsumi, M. D.

Second Department of Internal Medicine

Kobe University School of Medicine

7 chome, Kusunoki-cho, Ikuta-ku

Kobe

Japan 